\title{
Procoagulant activities in venoms from Central Asian snakes
}

Citation for published version (APA):

Yukelson, L. Y., Tans, G., Thomassen, M. C. L. G. D., Hemker, H. C., \& Rosing, J. (1991). Procoagulant activities in venoms from Central Asian snakes. Toxicon, 29(4-5), 491-502. https://doi.org/10.1016/00410101(91)90023-K

Document status and date:

Published: 01/01/1991

DOI:

10.1016/0041-0101(91)90023-K

Document Version:

Publisher's PDF, also known as Version of record

\section{Please check the document version of this publication:}

- A submitted manuscript is the version of the article upon submission and before peer-review. There can be important differences between the submitted version and the official published version of record.

People interested in the research are advised to contact the author for the final version of the publication, or visit the DOI to the publisher's website.

- The final author version and the galley proof are versions of the publication after peer review.

- The final published version features the final layout of the paper including the volume, issue and page numbers.

Link to publication

\footnotetext{
General rights rights.

- You may freely distribute the URL identifying the publication in the public portal. please follow below link for the End User Agreement:

www.umlib.nl/taverne-license

Take down policy

If you believe that this document breaches copyright please contact us at:

repository@maastrichtuniversity.nl

providing details and we will investigate your claim.
}

Copyright and moral rights for the publications made accessible in the public portal are retained by the authors and/or other copyright owners and it is a condition of accessing publications that users recognise and abide by the legal requirements associated with these

- Users may download and print one copy of any publication from the public portal for the purpose of private study or research.

- You may not further distribute the material or use it for any profit-making activity or commercial gain

If the publication is distributed under the terms of Article $25 \mathrm{fa}$ of the Dutch Copyright Act, indicated by the "Taverne" license above, 


\title{
PROCOAGULANT ACTIVITIES IN VENOMS FROM CENTRAL ASIAN SNAKES
}

\author{
L. Ya. Yukelson, ${ }^{1}$ G. Tans, ${ }^{2}$ M. C. L. G. D. Thomassen, ${ }^{2}$ H. C. Hemker ${ }^{2}$ \\ and J. Rosing ${ }^{2 *}$ \\ 'Institute of Biochemistry of the Uzbek Academy of Sciences, Tashkent, U.S.S.R. \\ and ${ }^{2}$ Department of Biochemistry, Cardiovascular Research Institute, \\ University of Limburg, Maastricht, The Netherlands
}

(Received 8 August 1990; accepted 14 November 1990)

L. Ya. Yukelson, G. Tans, M. C. L. G. D. Thomassen, H. C. Hemker and J. Rosing. Procoagulant activities in venoms from central Asian snakes. Toxicon 29, 491-502, 1991.-The venoms from central Asian snakes (Echis carinatus, Echis multisquamatus, Vipera ursini, Vipera lebetina, Agkistrodon halys halys and Naja naja oxiana) contain several enzymes with amidolytic- and procoagulant activity. We have characterized the activities and the mol. wts of the venom enzymes that are able to convert a number of commercially available chromogenic substrates for activated coagulation factors. The chromogenic substrate cleavage patterns obtained for the crude venoms may be helpful tools in the further identification of venom fractions and venom enzymes with procoagulant activity. The crude venoms were also tested for their ability to clot fibrinogen, to lyse fibrin polymers and to activate the coagulation factors prothrombin, factor $\mathrm{X}$ and factor $\mathrm{V}$. The products of venom-catalyzed coagulation factor activation were structurally characterized by SDS gel electrophoresis and were compared with activated coagulation factors that are generated under physiological conditions.

\section{INTRODUCTION}

SEVERAL snake venoms contain proteins that interfere with the hemostatic mechanism. There are many reports on venom proteins with procoagulant, anticoagulant or fibrinolytic activities (PIRKLe and Markland, 1988). Because of potential therapeutic and diagnostic applications such hemostatic factors are useful study objects. Since the mode of action of the venom proteins may differ from that of the corresponding mammalian enzymes, studies on the procoagulant action of venoms may also provide additional information on the mechanisms of the reactions that participate in the hemostatic process.

A large number of snake venom proteins have been described that are able to activate coagulation factors. In particular prothrombin, factor $\mathrm{X}$ and factor $\mathrm{V}$ are targets for activation by proteolytic enzymes present in the venoms of a wide variety of snakes. The venoms of several Echis (GITTER et al., 1960; SCHIECK et al., 1972), Bothrops species (NAhas et al., 1979; Hofmann and Bon, 1987a; Govers-RIEMSLAG et al., 1987), Dispholi-

\footnotetext{
*Author to whom correspondence should be addressed.
} 
dus typus (GuILlin et al., 1978) and Australian elapidae (TANS et al., 1985; SPEIJER et al., 1986) contain potent prothrombin activators. Factor $X$ activators are present in the venoms of Vipera russelli (SCHIFMANN et al., 1969), Echis carinatus (HEMKER et al., 1984; StOCKER et al., 1986), Cerastes cerastes (FRANSSEN et al., 1983) and Bothrops atrox (HOFMANN and BON, 1987b). Factor $\mathrm{V}$ is efficiently activated by a proteinase from the venom of Vipera russelli (SCHIFFMAN et al., 1969; KISIEL, 1979). The products of venomcatalyzed coagulation factor activation, which often differ from those obtained with the natural activators, are excellent tools in studying the structure-function relationship of blood coagulation factors.

In this paper we report a screening of the amidolytic- and procoagulant activities present in the venoms of a number of central Asian snakes originating from Uzbekistan, U.S.S.R. We have determined the content and the mol. wts of the venom proteins which exhibit amidolytic activity towards a number of chromogenic substrates. Furthermore, we have compared the abilities of the crude venoms to activate prothrombin, factor $\mathrm{X}$ and factor $\mathrm{V}$ and characterized the products, that are formed after activation by these venoms.

\begin{abstract}
Materials
MATERIALS AND METHODS

The venoms used in this study were supplied by the Institute of Biochemistry, Uzbek Academy of Sciences, Tashkent, U.S.S.R. and were dissolved at a concentration of $5 \mathrm{mg} / \mathrm{ml}$ in $50 \mathrm{mM}$ Tris, $175 \mathrm{mM} \mathrm{NaCl}$ and $2 \mathrm{mM}$ $\mathrm{CaCl}_{2}$. Non-soluble material was removed by centrifugation. The chromogenic substrates $\mathrm{H}-\mathrm{D}-\mathrm{Phenylalanyl-L-}$ pipecolyl-L-arginine-p-nitroanilide (S2238), N-Benzoyl-isoleucyl-L-glutamyl(piperidide)glycyl-L-arginine-pnitroanilide (S2337), L-Pyroglutamyl-L-prolyl-L-arginine-p-nitroanilide (S2366), H-D-Prolyl-L-phenylalanyl-Larginine-p-nitroanilide (S2302), H-D-Valyl-L-leucy]-L-lysine-p-nitroanilide (S2251), the thrombin inhibitor Ndansyl-(p-guanidino)phenylalanyl-piperidine hydrochloride (12581) and human fibrinogen were obtained from AB Kabi Diagnostica, Sweden. p-Nitrophenyl-p-guanidino-benzoate ( $p$-NPGB) was purchased from Nutritional Biochemicals Inc. Russell's viper venom, brain phosphatidylserine and egg yolk phosphatidylcholine were obtained from Sigma, St. Louis, MO, U.S.A.
\end{abstract}

\title{
Proteins
}

The blood coagulation factors used in this study were obtained from fresh frozen human plasma. Prothrombin and factor $X$ were purified according to the method of DI SCIPIO et al. (1977a). Factor V was isolated as described by Suzuki et al. (1982). Human factor Xa was obtained by the procedure of Bock et al. (1989). Bovine factor Xa was purified according to the method of Fujkawa et al. (1972). The molar concentrations of prothrombin and factor $\mathbf{X}$ were determined after complete activation with the venom of Echis carinatus and Russell's viper, respectively and subsequent active site titration with p-NPGB (CHASE and SHAw, 1969; SMrTH, 1973). The factor $V$ concentrations were determined kinetically after complete activation of factor $V$ with thrombin (LiNDHOUT et al., 1982).

\section{Assay of amidolytic activity}

Amidolytic activities towards the chromogenic substrates S2238, S2337, S2302, S2366, S2251 were measured at $37^{\circ} \mathrm{C}$ in a buffer containing $50 \mathrm{mM}$ tris(hydroxymethyl)aminomethane (Tris, pH 7.9), $175 \mathrm{mM} \mathrm{NaCl}, 2 \mathrm{mM}$ $\mathrm{CaCl}_{2}$ and $200 \mu \mathrm{M}$ chromogenic substrate. Generation of $p$-nitroaniline was determined on a dual-wavelength spectrophotometer by measuring $A_{405-500 \mathrm{~mm}}$ and using a molar extinction coefficient of $10,400 \mathrm{~mol}{ }^{\prime} .1 . \mathrm{cm}^{\prime \prime}$ ' for p-nitroaniline.

\section{Clotting and fibrinolytic activity}

The ability of the crude venoms to clot fibrinogen was determined in $350 \mu$ l of a reaction medium containing $50 \mathrm{mM}$ Tris (pH 7.9), $175 \mathrm{mM} \mathrm{NaCl}, 11.5 \mathrm{mM} \mathrm{CaCl}, 3 \mathrm{mg} / \mathrm{ml}$ fibrinogen and an appropriate amount of venom. Clot lysis (fibrinolysis) was measured in the same medium in which, prior to the addition of venom, the fibrinogen was allowed to clot with $5 \mathrm{nM}$ thrombin. 
Prothrombin activation

Rates of venom-catalyzed prothrombin activation were measured at $37^{\circ} \mathrm{C}$ in a reaction mixture containing $50 \mathrm{mM}$ Tris (pH 7.9), $175 \mathrm{mM} \mathrm{NaCl}, 5 \mathrm{mM} \mathrm{CaCl}, 1 \mu \mathrm{M}$ human prothrombin and an appropriate amount of crude venom. Thrombin and meizothrombin formation were determined with $\mathbf{S} 2238$ as described previously (Rosing et al., 1986).

\section{Factor $X$ activation}

Rates of venom-catalyzed factor $X$ activation were determined at $37^{\circ} \mathrm{C}$ in a reaction mixture containing $50 \mathrm{mM}$ Tris (pH 7.9), $175 \mathrm{mM} \mathrm{NaCl}, 5 \mathrm{mM} \mathrm{CaCl}_{2}, 1 \mu \mathrm{M}$ human factor $\mathrm{X}$ and an appropriate amount of crude venom. After different time intervals samples were taken and transferred to cuvettes containing $50 \mathrm{mM}$ Tris (pH 7.9), $175 \mathrm{mM} \mathrm{NaCl}, 20 \mathrm{mM}$ EDTA, $0.5 \mathrm{mg} / \mathrm{ml}$ ovalbumin and $200 \mu \mathrm{M} \mathrm{S2337.} \mathrm{The} \mathrm{conversion} \mathrm{of} \mathrm{S2337} \mathrm{was}$ followed by measuring $A_{405-500 \mathrm{~mm}}$ on a dual-wavelength spectrophotometer. From a calibration curve made with known concentrations of active site-titrated factor $\mathrm{Xa}$ the amounts of activated factor $\mathrm{X}$ in the reaction mixture could be calculated.

\section{Factor $V$ activation}

Rates of venom-catalyzed factor $\mathrm{V}$ activation were determined at $37^{\circ} \mathrm{C}$ in a reaction mixture containing $50 \mathrm{mM}$ Tris ( $\mathrm{pH} 7.9$ ), $175 \mathrm{mM} \mathrm{NaCl}, 5 \mathrm{CaCl}_{2}, 150 \mathrm{nM}$ factor $\mathrm{V}$ and appropriate amounts of crude venom. Factor $\mathrm{V}$ formation was determined as described below.

\section{Factor Va assay}

Factor Va was determined via its cofactor activity in the activation of prothrombin by factor Xa. For reasons of convenience, bovine factor $\mathrm{Xa}$ was used in the assay. Amounts of factor $\mathrm{Xa}$, phospholipid vesicles and prothrombin present in the assay were such that rates of prothrombin activation were linearly dependent on factor $\mathrm{Va}$, constant in time and were not influenced by small variations of the factor $\mathrm{Xa}$, phospholipid and prothrombin concentrations. In a typical experiment factor Va was quantitated as follows: to $235 \mu \mathrm{l}$ of a buffer solution (prewarmed at $37^{\circ} \mathrm{C}$ ) containing bovine factor $\mathrm{Xa}$ and phospholipid, $5 \mu \mathrm{l}$ prothrombin was added and after $15 \mathrm{sec}$ prothrombin activation was started with the addition of a $10 \mu \mathrm{l}$ aliquot containing factor Va. Final concentrations reached in the reaction mixture were: $50 \mathrm{mM}$ Tris (pH 7.9), $175 \mathrm{mM} \mathrm{NaCl}, 2 \mathrm{mM} \mathrm{CaCl}, 5 \mathrm{nM}$ factor $\mathrm{Xa}, 100 \mu \mathrm{M}$ phospholipid vesicles $(10 \%$ brain phosphatidylserine $/ 90 \%$ egg yolk phosphatidylcholine; $\mathrm{M} / \mathrm{M}), 1 \mu \mathrm{M}$ prothrombin, $0.5 \mathrm{mg} / \mathrm{ml}$ ovalbumin, $20 \mu \mathrm{M} I 2581$ and the factor Va from the aliquot. The phospholipid vesicles used in this assay were prepared as described by Rosing et al. (1980). The reversible thrombin inhibitor 12581 was present to prevent activation of any remaining factor $V$ by the thrombin that was formed in the assay. Prothrombin activation in the assay mixture was determined by measuring the thrombin formed after I min using the chromogenic substrate S2238 (Rosing et al., 1986). The amount of thrombin formed in this assay was linearly dependent on factor Va (up to some $60 \mathrm{pM}$ concentration of factor $\mathrm{Va}$ present in the assay mixture) and from a calibration curve made with known amounts of factor $\mathrm{Va}$ the amount of factor $V$ a present in the reaction mixture could be calculated. The 12581 present in the aliquots taken from the factor Va assay mixtures did not interfere with the thrombin determination since 12581 is a competitive inhibitor whose inhibitory action on thrombin was greatly reduced by dilution in the cuvette and by the presence of a large excess of the thrombin-specific substrate S2238.

\section{Gel electrophoretic techniques}

Electrophoresis was carried out on $7 \%$ (Fig. 5) or 10\% (Figs 1, 3 and 4) polyacrylamide slab gels (5\% stacking gel) according to the method of LAEMMLI et al., (1970) in a miniprotean II cell from BioRad. After electrophoresis the proteins were either stained with Coomassie brilliant blue R250 or they were transferred electrophoretically to nitrocellulose sheets as described by TowBIN et al. (1979). Transfer was routinely performed overnight at $10^{\circ} \mathrm{C}$ with $125 \mathrm{~mA}$ current in a Protean II blot module from Biorad. Amidolytic detection of proteins bound to the nitrocellulose sheets was performed as described by TANS $e t$ al. (1989).

\section{RESULTS}

\section{Amidolytic activities of central Asian snake venoms}

In this study we investigated the procoagulant activities present in the venoms of Echis carinatus, Echis multisquamatus, Vipera ursini, Vipera lebetina, Agkistrodon halys halys and Naja naja oxiana. To get an impression of the venom enzymes that might participate 
TABle 1. Amidolytic activtties of Central Asian sNake venoms

\begin{tabular}{lccccc}
\hline & \multicolumn{5}{c}{$\begin{array}{c}\text { Amidolytic activity } \\
\text { (nmole p-NA*/min/ } / \text { g venom) }\end{array}$} \\
Venom & $\mathrm{S} 2338$ & $\mathrm{~S} 2337$ & $\mathrm{~S} 2366$ & $\mathrm{S2302}$ & $\mathrm{S2251}$ \\
\hline Echis carinatus & 1.74 & 0.084 & 0.043 & 1.5 & 0.031 \\
Echis multisquamatus & 6.67 & 0.41 & 0.056 & 9.15 & 0.071 \\
Vipera ursini & 0.27 & 0.01 & 0.041 & 0.73 & 0.07 \\
Vipera lebetina & 1.32 & 0.23 & 0.24 & 20.7 & 0.05 \\
Agkistrodon halys halys & 0.81 & 0.06 & 0.16 & 7.96 & 0.38 \\
Naja naja oxiana & 0.01 & $<0.002$ & $<0.002$ & $<0.002$ & $<0.002$ \\
\hline
\end{tabular}

* $p$-NA $=p$-nitroaniline.

The amidolytic activity of the crude venoms was determined as described under Materials and Methods. The results given represent the average of three determinations. The standard errors were approximately $1.2 \%$.

in coagulation factor activation we first determined the activities of the crude venoms towards a number of commercially available chromogenic substrates that were designed for activated coagulation factors. Venom-catalyzed chromogenic substrate conversion was measured with the thrombin substrate S2338, the factor Xa substrate S2337, the activated protein C/factor XIa substrate S2366, the kallikrein substrate S2302 and the plasmin substrate S2251 (Table 1). With the exception of Naja naja oxiana all venoms exhibited considerable activity towards S2238 and S2302. The factor Xa substrate S2337 was converted at an appreciable rate by the venoms from Echis multisquamatus and Vipera lebetina and the highest activities towards S2366 were measured with the venoms from Vipera lebetina and Agkistrodon halys halys. The latter venom also contained an enzyme that readily converted the plasmin substrate $\mathbf{S 2 2 5 1}$. This substrate was, however, hardly susceptible to hydrolysis by the venoms from the Echis, Vipera and Naja species that we have tested. The venom from Naja naja oxiana had a very low activity towards S2238 and contained negligible activities towards the other chromogenic substrates.

$\mathbf{A}$
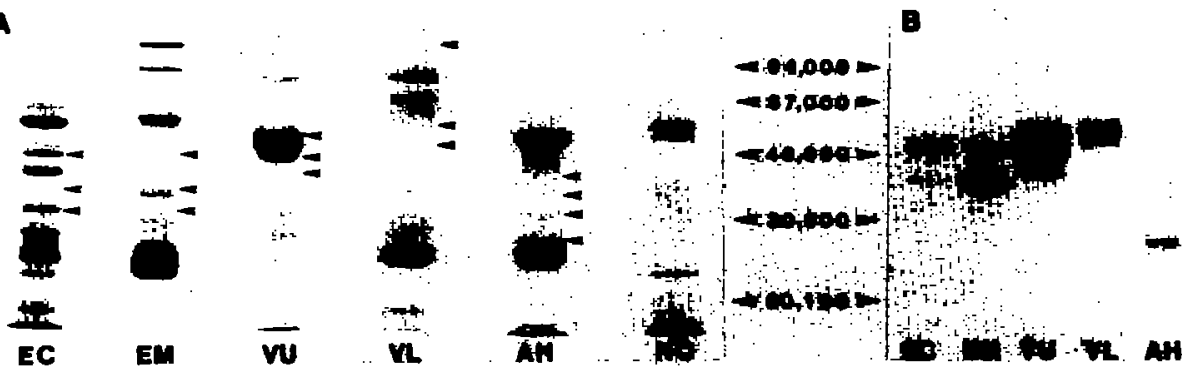

FIG. 1. SDS-GRL ELECTROPHORETIC ANALYSIS OF CENTRAL ASIAN SNAKE VENOMS.

(A) $10 \mu \mathrm{l}$ samples containing $20 \mu \mathrm{g}$ of crude venom were electrophoresed on $10 \%$ polyacrylamide slab gels in the presence of SDS as described by LABMMLI (1970). After electrophoresis the proteins were stained with Coomassie brilliant blue R250. (B) $30 \mu \mathrm{l}$ samples containing crude venom (33 $\mu \mathrm{g}$ Echis carinatus, EC; $10 \mu \mathrm{g}$ Echis multisquamatus, EM; $150 \mu \mathrm{g}$ Vipera ursini, VU; $5 \mu \mathrm{g}$ Vipera lebetina. VL; $15 \mu \mathrm{g}$ Agkistrodon halys halys, AH; $150 \mu \mathrm{g}$ Naja naja oxiana, NO) were electrophoresed on $10 \%$ polyacrylamide slab gels in the presence of SDS by the method of LAEmMI (1970). The proteins were subsequently transferred to a nitrocellulose membrane and visualized with S2302 as described under Materials and Methods. The migration distances of reference proteins with known mol. wts are indicated in the figure. The positions of amidolytically active products are marked in the Coomassie brilliant blue stained gel with arrows. 
TABLE 2. Molecular Weights of amidolytically aCtive proteins present in CEnTRal Asian sNake Venoms

\begin{tabular}{|c|c|c|c|c|c|}
\hline Venom & $\mathbf{S} 2238$ & $\mathbf{S 2 3 3 7}$ & $\begin{array}{l}\text { lar weight } \\
\text { S2366 }\end{array}$ & $\mathbf{S} 2302$ & S2251 \\
\hline Echis carinatus & $\begin{array}{c}38(++) \dagger \\
31( \pm)\end{array}$ & $\begin{array}{c}38(++) \\
31( \pm)\end{array}$ & $31(+)$ & $\begin{array}{c}46(++) \\
38(+) \\
31( \pm)\end{array}$ & $\begin{array}{c}46(+) \\
38( \pm) \\
31(++)\end{array}$ \\
\hline Echis multisquamatus & $\begin{array}{c}38(++) \\
31( \pm)\end{array}$ & $\begin{array}{c}38(++) \\
31( \pm)\end{array}$ & $31(+)$ & $\begin{array}{c}46(+) \\
38(++) \\
31( \pm)\end{array}$ & $\begin{array}{c}46(+) \\
38( \pm) \\
31(++)\end{array}$ \\
\hline Vipera ursini & $46(++)$ & - & $41( \pm)$ & $\begin{array}{l}52(++) \\
44(++) \\
41(++)\end{array}$ & $41(++)$ \\
\hline Vipera lebetina & $\begin{array}{c}135( \pm) \\
56(++) \\
47(+) \\
29( \pm)\end{array}$ & $47(++)$ & $\begin{array}{l}135(+) \\
56(++)\end{array}$ & $\begin{array}{l}135( \pm) \\
56(++) \\
47(++)\end{array}$ & $56(++)$ \\
\hline Agkistrodon halys halys & $\begin{array}{l}34( \pm) \\
31( \pm) \\
26( \pm)\end{array}$ & - & - & $\begin{array}{c}38(+) \\
34(+) \\
31(+) \\
26(++)\end{array}$ & $26( \pm)$ \\
\hline Naja naja oxiana & 一 & - & - & - & - \\
\hline
\end{tabular}

*Mol.wts of amidolytically active proteins were determined by the amidoblot procedure described under Materials and Methods. SDS-gel electrophoresis was carried out with $30 \mu \mathrm{l}$ samples containing $125 \mu \mathrm{g}$ crude venom (S2238, S2337, S2366 and S2251) or amounts of venom indicated in the legend to Fig. 1 (S2302).

tIntensities of amidolytically active protein bands are indicated by $(++)$ high, $(+)$ intermediate and $( \pm)$ low. — indicates the absence of amidolytically active bands.

\section{Molecular weights of venom enzymes with amidolytic activity}

In a previous paper (TANS et al., 1989) we described a procedure which allows detection of enzymes with amidolytic activity after SDS-gel electrophoresis. This method was used to determine the mol. wts of the amidolytically active venom enzymes. The crude venoms were subjected to SDS-gel electrophoresis on polyacrylamide slab gels. One gel was directly stained with Coomassie brilliant blue to obtain information about the mol. wts of the different proteins present in the crude venoms (Fig. 1A). Another gel was blotted onto a nitrocellulose membrane. After the removal of SDS the nitrocellulose-bound enzymes were visualized by placing the nitrocellulose sheet on an agarose gel with chromogenic substrate. In this set up amidolytically active proteins generate yellow bands, which can be photographed by transillumination with u.v.-A light.

As a typical example we show the amidoblot of the crude venoms that was developed with S2302 (Fig. 1B). Multiple bands with various mol. wts were observed for the venoms from Echis carinatus, Echis multisquamatus, Vipera ursini, Vipera lebetina and Agkistrodon halys halys. Echis carinatus venom contained three proteins that were able to convert S2302; two of these with apparent mol. wts of 46,000 and 38,000 were clearly visible while the third protein at 31,000 was only faintly visible. The crude venom of Echis multisquamatus showed three amidolytically active protein bands with apparent mol. wts of 46,000, 38,000 and 31,000 respectively. The $\mathbf{S} 2302$-converting activity of the venom of Vipera ursini was associated with proteins with mol. wts of 52,000, 44,000 and 41,000. Vipera lebetina contained three proteins that were active on $\mathbf{S} 2302$ and which had mol. wts of $135,000,56,000$ and 47,000 , respectively. The proteins with amidolytic activity on $\mathbf{S 2 3 0 2}$ that were present in the venom of Agkistrodon halys halys had rather low mol. wts $(38,000$, $34,000,31,000$ and 26,000 ). To get an impression of which proteins in the crude venom 
Table 3. Coagulation factor activation by central Astan snake venoms

\begin{tabular}{lccc}
\hline Venom & $\begin{array}{c}\text { Prothrombin } \\
\text { (nmoles activated/min/mg venom) }\end{array}$ & Factor V \\
\hline Echis carinatus & 81.5 & 2.3 & 0.64 \\
Echis multisquamatus & 187.4 & 0.36 & 0.24 \\
Vipera ursini & 0.004 & 18.6 & 1.32 \\
Vipera lebetina & 0.014 & 37.9 & 3.9 \\
Agkistrodon halys halys & 0.006 & 0.002 & 0.025 \\
Naja naja oxiana & 0.002 & 0.0002 & - \\
\hline
\end{tabular}

-, no detectable activation.

Coagulation factor activation was determined at $37^{\circ} \mathrm{C}$ in a reaction buffer containing $50 \mathrm{mM}$ Tris- $\mathrm{HCl}$ ( $\mathrm{pH} 7.9$ ), $175 \mathrm{mM} \mathrm{NaCl}, 5 \mathrm{mM} \mathrm{CaCl}, 0.5 \mathrm{mg} / \mathrm{ml}$ ovalbumin, appropriate amounts of crude venom, and $1 \mu \mathrm{M}$ prothrombin or $1 \mu \mathrm{M}$ factor $\mathrm{X}$ or $150 \mathrm{nM}$ factor $\mathrm{V}$. Further experimental details are described under Materials and Methods. The standard error in the rates obtained (averaged from three rate measurements) was $2.5 \%$ in the case of prothrombin or factor $\mathrm{X}$ activation and $6 \%$ in the case of factor $\mathrm{V}$ activation.

were amidolytically active we have indicated the migration distances of the enzymes with amidolytic activity towards S2302 with an arrow in the Coomassie blue-stained gel of the crude venoms (Fig. 1A).

The chromogenic substrates S2238, S2337, S2366 and S2251 were also used to develop the amidoblot of the crude venoms (data not shown). In Table 2 we have summarized the apparent mol. wts of the venom enzymes with amidolytic activity towards the different chromogenic substrates. The data presented in this table indicate that in a number of cases the amidolytic enzymes, that convert the different chromogenic substrates, had the same mol. wts. Since it is well known that chromogenic substrates are not fully specific for a single proteolytic enzyme it is possible that the same venom enzyme cleaves more than one chromogenic substrate, which may explain the comigration of the different amidolytic activities.

\section{Venom-catalyzed coagulation factor activation}

The crude venoms were also tested for their ability to activate the coagulation factors that participate in the so-called prothrombinase complex i.e. prothrombin, factor $V$ and factor $X$ (Table 3). For comparison we have also determined whether the venoms contain clotting activity (fibrinogen to fibrin conversion) and fibrinolytic activity.

Prothrombin was activated at considerable rates by the venoms from Echis carinatus and Echis multisquamatus. The other venoms contained prothrombin-converting activities that were more than $10^{4}$-fold lower than obtained with the Echis species. The products that were generated during venom-catalyzed prothrombin activation were very slowly inhibited by a mixture of $4 \mathrm{nM}$ antithrombin III and $10 \mu \mathrm{g} / \mathrm{ml}$ heparin (data not shown). Since thrombin would be readily inhibited by such a mixture (Rosing et al., 1986) this indicates that the venoms convert prothrombin into meizothrombin or meizothrombindes-fragment 1 (a more detailed description of the various reaction products that can be formed during prothrombin activation is given in the next paragraph).

Very low amounts of Vipera ursini and Vipera lebetina venom were required to fully activate factor $\mathrm{X}$, which indicates that both Vipera species contain a very potent factor $\mathrm{X}$ activator. The venoms from Echis carinatus and Echis multisquamatus also rapidly 


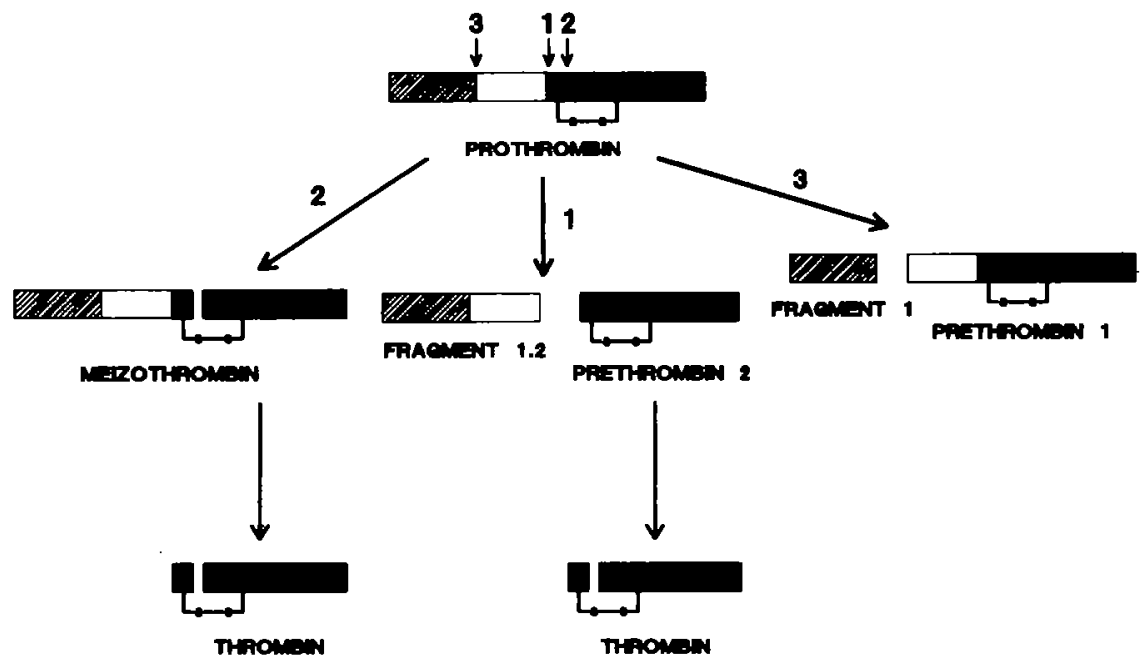

Fig. 2. Prothrombin activation products.

The activation of prothrombin can give rise to a rather complex gel electrophoretic pattern due to the fact that the prothrombin molecule $(72,000)$ is susceptible to proleoytic cleavage at more than one peptide bond. The three most important cleavage sites are shown in the figure. Cleavage of bonds $1\left(\mathrm{Arg}_{273}-\mathrm{Thr}_{274}\right)$ and $2\left(\mathrm{Arg}_{322}-\mathrm{Ile}_{323}\right)$ by factor $\mathrm{Xa}$ are necessary for thrombin formation. Cleavage at bond 2 results in exposure of the active site. Thus, depending on which bond is cleaved first the active enzyme meizothrombin $(72,000)$ or the inactive precursor of thrombin, i.e. prethrombin $2(36,000)$ together with the activation peptide fragment $1.2(36,000)$ are formed. The reaction products meizothrombin and thrombin can autocatalytically cleave at bond 3 $\left(\mathrm{Arg}_{155}-\mathrm{Ser}_{156}\right)$ resulting in the removal of fragment $1(24,000)$. Depending on whether this cleavage occurs in prothrombin or meizothrombin so-called prethrombin $1(48,000)$ or meizothrombin-desfragment $1(48,000)$ are formed. The final product thrombin $(36,000)$ is a two-chain enzyme consisting of the so-called A-chain $(5,000)$ and the active site containing B-chain $(31,000)$.

activated factor X, while those from Agkistrodon halys halys and Naja naja oxiana were not able to convert factor $\mathrm{X}$ into a catalytically active product.

Factor $\mathrm{V}$ could be activated by all venoms except the one from Naja naja oxiana. Especially the venoms from Vipera ursini and Vipera lebetina contained a considerable amount of factor $\mathrm{V}$ activator. Factor $\mathrm{V}$ activation had to be measured at a proper concentration of crude venom since all venoms also contained a factor $\mathrm{Va}$ inactivator. When time courses of factor $V$ activation were determined at high venom concentrations, the factor Va generated in the reaction mixture rapidly lost its activity. We do as yet not know whether it was the same enzyme that was responsible for factor $V$ activation and factor $\mathrm{Va}$ inactivation. The venoms produced a factor $\mathrm{Va}$ molecule that was functionally different from thrombin-activated factor $V$. When tested on their ability to stimulate prothrombin activation, the venom-activated factor $\mathrm{Va}$ preparations had $50 \%$ of the activity of factor $\mathrm{Va}$ that is formed by thrombin. This difference may be caused by structural differences between venom- and thrombin activated factor $\mathrm{V}$ (see below).

Direct conversion of fibrinogen into fibrin, i.e. clot formation, was only observed with the venom from Agkistrodon halys halys. This venom also contained a large amount of a fibrinolytic enzyme since prolonged incubation of the fibrin polymer with the venom resulted in clot lysis. The venom from Echis multisquamatus, Vipera lebetina, Vipera ursini and Naja naja oxiana did not clot fibrinogen. These latter venoms did, however, express low to intermediate fibrinolytic activities since they were able to dissolve clots that were formed in fibrinogen solutions by thrombin. 
Structural properties of venom-activated coagulation factors

The products formed after activation of the different coagulation factors with the crude venoms were analyzed after SDS gel electrophoresis and identified by protein staining with Coomassie brilliant blue.

Due to the fact that at least three peptide bonds in prothrombin are susceptible to proteolytic cleavage a large number of activation products may be observed during prothrombin activation. The major prothrombin activation products that can be formed during factor Xa-catalyzed prothrombin activation are given in Fig. 2 together with their respective mol. wts (for a review on prothrombin activation see also Rosing and TANS, 1988). Two products were formed when prothrombin was activated by the venoms from Echis carinatus and Echis multisquamatus (Fig. 3A). They comigrated with prethrombin 1 $\left(M_{\mathrm{r}}=48,000\right)$ and fragment $1\left(M_{\mathrm{r}}=24,000\right)$. Gel electrophoretic analysis of reduced reaction samples (Fig. 3B) showed that a peptide bond was cleaved in the 48,000 reaction product since after reduction bands comigrating with so-called fragment 2-A and thrombin B-chain appeared on the gel (c.f. RosING and TANS, 1988). This indicates that meizothrombin-des-fragment $1\left(M_{\mathrm{r}}=48,000\right)$ was the major product of Echis-catalyzed prothrombin activation. However, it is likely that meizothrombin was the primary reaction product and that meizothrombin-des-fragment 1 was formed by autocatalytic removal of the fragment 1 domain. This is concluded from observations that autocatalysis is a rather efficient process (Rosing et al., 1986) and that meizothrombin-des-fragment 1 formation in the venom/prothrombin mixtures was greatly reduced by 12581 , a potent inhibitor of thrombin and meizothrombin (data not shown). The gel electrophoretic analysis indicates that the other venoms were not able to convert prothrombin into enzymatically active products (see also Table 3 ). These venoms did, however, contain enzymes that cleaved peptide bonds in prothrombin, generating products that comigrated

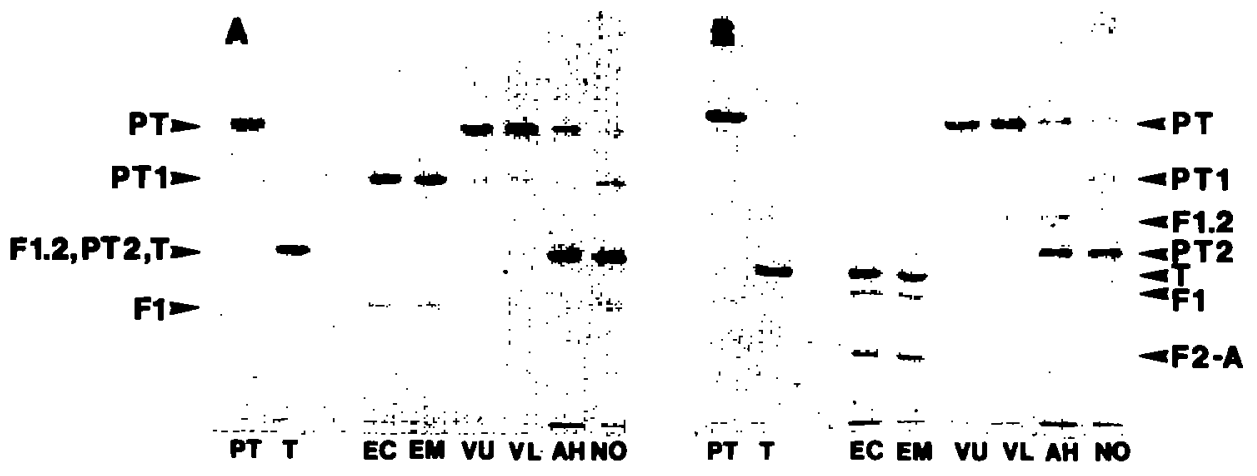

FIG. 3. SDS-GEL ELECTROPHORETIC ANALYSIS OP PROTHROMBn ACTIVATION BY CENTRAL ASIAN SNAKE VENOMS.

Prothrombin $(2 \mu \mathrm{M})$ was activated for variable time intervals in a buffer containing $50 \mathrm{mM}$ Tris$\mathrm{HCl}$ (pH 7.9), $175 \mathrm{mM} \mathrm{NaCl}, 5 \mathrm{mM} \mathrm{CaCl}$ and $25 \mu \mathrm{g} / \mathrm{ml}$ crude venom. The activation times were: 4 min with Echis carinatus (EC) and Echis multisquamatus (EM) or $60 \mathrm{~min}$ with Vipera ursini (VU), Vipera lebetina (VL), Agkistrodon halys halys (AH) and Naja naja oxiana (NO). After activation $10 \mu \mathrm{l}$ aliquots from the reaction mixtures were mixed with $15 \mu \mathrm{l}$ of SDS-gel electrophoresis buffer (LAEMML, 1970) without (A) or with $5 \%$ (v/v) mercaptoethanol (B). After electrophoresis the gels were stained with Coomassie brilliant blue. The first two lanes of each gel contain pure prothrombin (PT) and thrombin (T), respectively. Further abbreviations used are: PT1 = prethrombin 1; F1.2 = fragment 1.2; PT2 = prethrombin 2; F1 = fragment $1 ;$ F2-A = fragment 2-A. 
with prethrombin 1 (Vipera ursini, Vipera lebetina and Naja naja oxiana) or prethrombin 2 (Agkistrodon halys halys and Naja naja oxiana).

The heavy chain of factor $\mathrm{X}$ was highly susceptible to proteolytic cleavage by enzymes present in the venoms that we have tested (Figs $4 \mathrm{~A}, \mathrm{~B}$ ). In those cases in which heavy chain cleavage was accompanied by factor $\mathrm{Xa}$ formation (i.e. with the Echis and Vipera species), the products migrated at 34,000 and 30,000, which corresponds to the mol. wts of the heavy chains of factors $\mathrm{Xa}_{\alpha}$ and $\mathrm{Xa}_{\beta}$, respectively (DI SCIPIO et al., 1977b; MERTENS and BERTINA, 1980; BocK et al., 1989). The venoms from Agkistrodon halys halys and Naja naja oxiana were also able to cleave the heavy chain of factor $\mathrm{X}$ generating peptides with mol. wts of 40,000 and 43,000 , respectively. These peptide bond cleavages did, however, not result in active site exposure.

The factor Va produced after venom activation is structurally different from thrombinactivated factor $\mathbf{V}$ (Fig. 5). When factor $\mathrm{V}$ was activated by thrombin four major protein bands appeared on the gel with respective mol. wts of $150,000,105,000,74,000$ and 71,000 . The 150,000 and 71,000 bands (designated $C$ and $E$ respectively according to the notation proposed by DAHLBACK, 1980) are activation peptides and the 105,000 and 74,000 bands ( $D$ and F1F2) are subunits of factor $\mathrm{Va}$, which are associated via $\mathrm{Ca}^{2+}$ ion in the native factor Va molecule (DAHLBACK, 1980; SUzUKI et al., 1982). Factor V activation by the crude venoms, that were the subjects of this study, resulted in the formation of activation fragments that were different from those obtained after activation with thrombin. With both Echis species activation fragments were formed with $M_{\mathrm{r}}<71,000$ while the factor Va generated by Vipera lebetina does not contain the D-chain characteristic for thrombinactivated factor $V$. These structural differences between venom- and thrombin-activated factor V may explain why they are functionally different (see above). With the crude venom of Agkistrodon halys halys only transient activation of factor Va was obtained since under all circumstances the activation was accompanied by a rapid loss of factor $\mathrm{Va}$ activity. Thus, no stable plateau of factor $\mathrm{Va}$ activity could be reached and the product

A

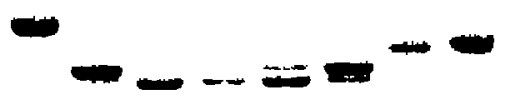

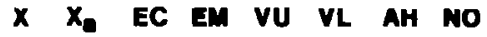

B

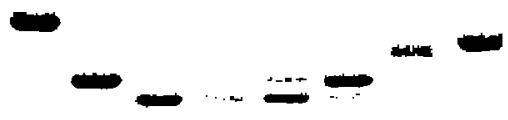

$X x_{a}$ EC EM VU VL AH NO

Fig. 4. SDS-gel ELECTROPHORETIC ANALYSIS OF FACTOR X ACTIVATION bY CENTRAL ASIAN SNAKE VENOMS.

Factor $\mathrm{X}(5 \mu \mathrm{M})$ was activated for variable time intervals in a buffer containing $50 \mathrm{mM}$ Tris-HCl (pH 7.9), $175 \mathrm{mM} \mathrm{NaCl}, 5 \mathrm{mM} \mathrm{CaCl}$ and $50 \mu \mathrm{g} / \mathrm{ml}$ crude venom. The activation times were: $24 \mathrm{hr}$ with Echis carinatus (EC), Echis multisquamatus (EM), Agkistrodon halys halys (AH) and Naja naja oxiana (NO) or $5 \mathrm{hr}$ with Vipera ursini (VU) and $1 \mathrm{hr}$ with Vipera lebetina (VL). After the activation times indicated above $10 \mu \mathrm{l}$ aliquots from the reaction mixtures were mixed with $15 \mu \mathrm{l}$ of SDS-gel electrophoresis buffer (LAEMMLI, 1970) without (A) or with $5 \%$ (v/v) mercaptoethanol (B). After electrophoresis the gels were stained with Coomassie brilliant blue. The first two lanes of the gel contain pure factor $X$ and factor $X a$, respectively. Further abbreviations used are: $X=$ factor $\mathrm{X} ; \mathrm{Xa}=$ factor $\mathrm{Xa} ; \mathrm{Xa}_{\beta}=\beta$-factor $\mathrm{Xa} ; \mathrm{X}_{\mathrm{HC}}=$ heavy chain of factor $\mathrm{X} ; \mathrm{Xa}_{\mathrm{HC}}=$ heavy chain of factor $\mathrm{Xa} ; \mathrm{Xa}_{\beta \mathrm{HC}}=$ heavy chain of $\beta$-factor $\mathrm{Xa} ; \mathbf{L C}=$ light chain of factor $\mathrm{X}$, factor $\mathrm{Xa}$ and $\beta$-factor Xa. 


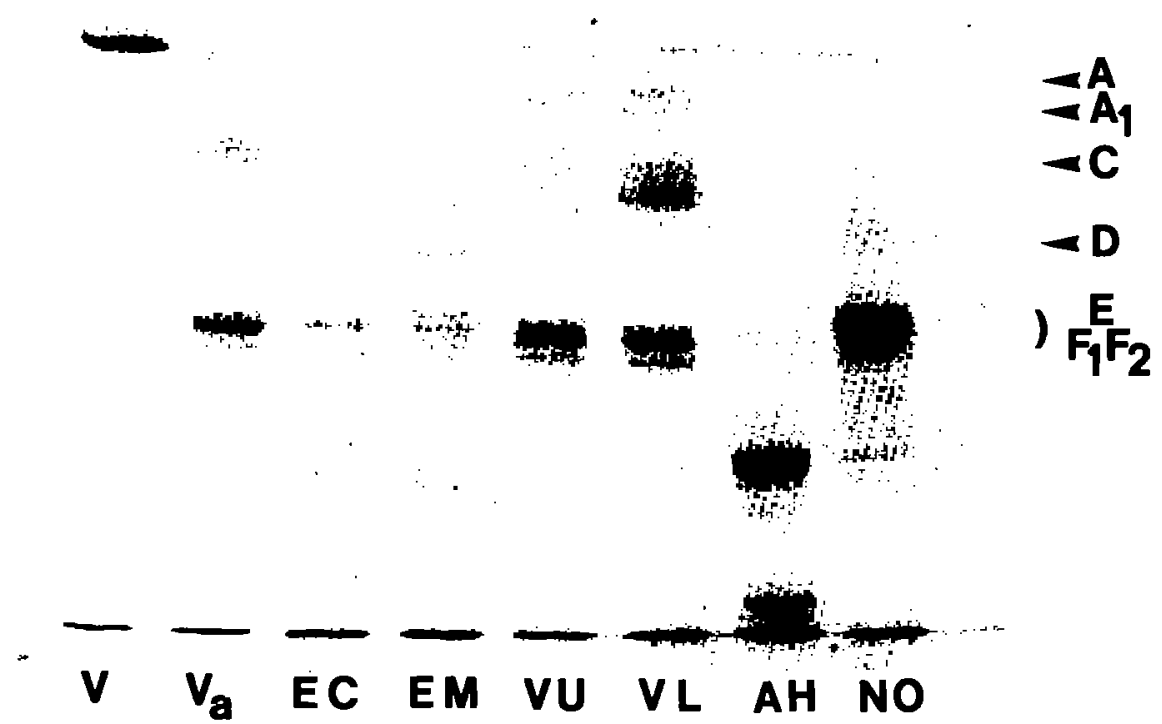

Fig. 5. SDS-GEI ELECTROPHORETIC ANALYSIS OF FACTOR V ACTTVATION BY CENTRAL ASIAN SNAKE VENOMS.

Factor $\mathrm{V}(1 \mu \mathrm{M})$ was activated in a reaction mixture containing $50 \mathrm{mM}$ Tris- $\mathrm{HCl}$ (pH 7.9), $175 \mathrm{mM} \mathrm{NaCl}, 5 \mathrm{mM} \mathrm{CaCl}$ and crude venom. The concentrations of venom and the activation times were: Echis carinatus (EC, $25 \mu \mathrm{g} / \mathrm{ml}, 10 \mathrm{~min}$ ), Echis multisquamatus (EM, $100 \mu \mathrm{g} / \mathrm{ml}, 6 \mathrm{~min}$ ), Vipera ursini (VU, $10 \mu \mathrm{g} / \mathrm{ml}, 25 \mathrm{~min}$ ), Vipera lebetina (VL, $5 \mu \mathrm{g} / \mathrm{ml}, 25 \mathrm{~min}$ ), Agkistrodon halys halys (AH, $250 \mu \mathrm{g} / \mathrm{ml}, 10 \mathrm{~min}$ ) and Naja naja oxiana (NO, $250 \mu \mathrm{g} / \mathrm{ml}, 25 \mathrm{~min})$. After the activation times indicated above $15 \mu \mathrm{l}$ aliquots from the reaction mixtures were mixed with $5 \mu \mathrm{l}$ SDS-gel electrophoresis buffer (LAEMMLI, 1970). The samples were electrophoresed on 7\% polyacrylamide slab gels, which were subsequently stained with Coomassie brilliant blue. Lane 1 contains factor $V$ (V) and lane 2 contains thrombin-activated factor $\mathrm{V}(\mathrm{Va})$. To indicate activation peptides and subunits of factor $\mathrm{Va}$ on the gel we have used the terminology of Suzuki et al. (1982). A = factor V $\left(M_{\mathrm{r}}=330,000\right), \mathrm{A}_{1}=$ activation intermediate $\left(M_{\mathrm{r}}=280,000\right), \mathrm{C}=$ activation fragment $\left(M_{\mathrm{r}}=\right.$ $150,000), D=$ heavy chain of factor $\mathrm{Va}\left(M_{\mathrm{r}}=105,000\right), \mathrm{F} 1 / \mathrm{F} 2=$ light chain of factor $\mathrm{Va}$ $\left(M_{\mathrm{r}}=74,000 / 71,000\right)$ and $\mathrm{E}=$ activation fragment $\left(M_{\mathrm{r}}=71,000\right)$.

shown in the gel is the final (inactive) reaction product. This is corroborated by the extensive degradation of factor $\mathrm{V} / \mathrm{Va}$ that was apparent from the gel. Finally, Naja naja oxiana was also capable of proteolysing factor V. However, this proteolysis was not accompanied by expression of factor Va activity (cf. also Table 3 ).

\section{DISCUSSION}

The venoms from the central Asian snakes (Echis carinatus, Echis multisquamatus, Vipera ursini, Vipera lebetina, Agkistrodon halys halys and Naja naja oxiana) that were investigated in the present study contain a wide variety of amidolytic and procoagulant activities. Dependent on the snake species a large number of coagulation factor-specific chromogenic substrates are cleaved by the crude venom preparations (Table 1). Since chromogenic substrates are not fully specific for a single coagulation factor or proteolytic enzyme, venom activity towards a certain chromogenic substrate does not necessarily mean that the crude venom contains an enzyme that shares coagulant properties with the corresponding activated coagulation factor. However, in some cases it will be one and the same enzyme that is responsible for both amidolytic activity and coagulation factor 
activation. In such instances the chromogenic substrate cleavage patterns and mol. wt determinations by the amidoblot procedure (Fig. 1 and Table 2) will be useful tools in a rapid and easy comparison (identification and quantification) of the procoagulant activity present in the crude venoms or in the venom fractions from different snakes belonging to the same species or genus.

Several coagulation factors were susceptible to peptide bond cleavage and activation by proteolytic enzymes present in the crude venoms. The venom from Agkistrodon halys halys readily converts fibrinogen into fibrin and also contains a considerable amount of fibrinolytic activity. Low fibrinolytic activities were observed in Vipera lebetina and Vipera ursini.

Prothrombin was rapidly converted into meizothrombin by the crude venoms of both Echis carinatus and Echis multisquamatus. Meizothrombin has been reported to be the major product of prothrombin activation by enzymes present in the venoms of several snake species (GITTER et al., 1960; SCHIECK et al., 1972; Govers-RIEMSLAG et al., 1987; GuILlin et al., 1978; HoFMANN and BoN, 1978a) and it is likely that the meizothrombindes-fragment 1 that was generated during venom-catalyzed prothrombin activation is not produced by the action of a venom enzyme, but was formed by autocatalytic removal of the fragment 1 domain. The venoms from Vipera ursini, Vipera lebetina, Agkistrodon halys halys and Naja naja oxiana also cleaved peptide bonds in prothrombin. These cleavages resulted in the production of prothrombin fragments that had mol. wts similar to prethrombin 1, prethrombin 2 and fragment 1 and that lack catalytic activity.

The crude venoms from both Echis and Vipera species contained considerable amounts of a factor $\mathrm{X}$-activating enzyme that generated a factor $\mathrm{Xa}$ molecule with structural properties identical to the factor $\mathrm{Xa} \alpha$ that is formed by Vipera russelli (Di ScIPIO et al., $1977 b$ ) or by the activated coagulation factors VIIa and IXa (MERTENS and BerTINA, 1980). Upon prolonged incubation of factor $X$ with these venoms heavy chain fragments were formed which migrated at somewhat lower apparent mol. wt. These fragments were presumably produced by autocatalytic proteolysis and were identical to the heavy chain of so-called factor $\mathrm{Xa}_{\beta}$ (Di Scipio et al., 1977b; Mertens and Bertina, 1980).

Factor $\mathrm{V}$ activators were present in the venoms of Echis carinatus, Echis multisquamatus, Vipera ursini and Vipera lebetina. Incubation of factor $\mathrm{V}$ with these activators resulted in the formation of activation fragments that were different from those obtained during factor $\mathrm{V}$ activation by thrombin (Fig. 5). Compared with thrombin-activated factor $\mathrm{V}$, the factor $\mathrm{Va}$ molecules that were produced during venom-catalyzed factor $\mathrm{V}$ activation had about $50 \%$ cofactor activity in prothrombin activation. With Agkistrodon halys halys only transient factor Va formation could be observed.

With respect to our data on venom-catalyzed coagulation factor activation it is not surprising that Echis multisquamatus contains a prothrombin and a factor $\mathrm{X}$ activator and that the venoms from Vipera ursini and Vipera lebetina activate factor $\mathrm{X}$ and factor $\mathrm{V}$ since similar activities are known to be present in the venoms of Echis carinatus (SCHIECK et al., 1972; HeMKER et al., 1984; STOCKER et al., 1986) and Vipera russelli (SCHIFFMANN et al., 1969), respectively. To the best of our knowledge our paper is, however, the first report on the presence of factor V-activating enzymes in the venoms of Echis and Agkistrodon species. Further characterization of these factor $\mathrm{V}$ activators is now in progress.

Acknowledgements-We thank TruUS JANSSEN-ClAessen for technical assistance. Part of the chromogenic substrates used in this study were kindly donated by AB Kabi Diagnostica. 


\section{REFERENCES}

Bock, P. E., Craig, P. A., Olson, S. T. and Singh, P. (1989) Isolation of human blood coagulation $\alpha$-factor Xa by soybean trypsin inhibitor-Sepharose chromatography and its active site titration with fluorescein mono-pguanidinobenzoate. Arch. Biochem. Biophys. 273, 375-388.

Chase, T. and Shaw, E. (1969) Comparison of the esterase activities of trypsin, plasmin and thrombin with guanidinobenzoate esters, titration of the enzymes. Biochemistry 8, 2212-2224.

DAHLBACK, B. (1980) Human coagulation factor V, purification and thrombin-catalyzed activation. J. Clin. Invest. 66, 583-591.

Di Scipio, R. G., Hermodson, M. A., Yates, S. G. and DAvie, E. W. (1977a) A comparison of human prothrombin, factor IX (Christmas factor), factor X (Stuart factor), and protein S. Biochemistry 16, 698-706.

Di Scipio, R. G., Hermodson, M. A. and DAviE, E. W. (1977b) Activation of human factor X (Stuart factor) by a protease from Russell's viper venom. Biochemistry 16, 5253-5260.

Franssen, J. H. L., Janssen-Claessen, T. and Van DieiJen, G. (1983) Purification and properties of an activating enzyme of blood coagulation factor $\mathbf{X}$ from the venom of Cerastes cerastes. Biochim. biophys. Acta 747, 186-190.

Fujikawa, K., Legaz, M. E. and DAviE, E. W. (1972) Bovine factor Xl (Stuart factor). Mechanism of activation by a protein from Russell's viper venom. Biochemistry 11, 4892-4899.

Gitter, S., Levi, G., Kochwa, S., De Vrifs, A., Rechnic, J. and Casper, J. (1960) Studies on the venom of Echis coloratus. Am. J. Trop. Med. Hyg. 9, 391-395.

Govers-Riemslag, J. W. P., KNapen, M. J. H., Tans, G., Zwanl, R. F. A. and Rosing, J. (1987) Structural and functional characterization of a prothrombin activator from the venom of Bothrops neuwiedi. Biochim. biophys. Acta 916, 388-401.

Gullin, M. C., Bezeaud, A. and MenaChe, D. (1978) The mechanism of activation of human prothrombin by an activator isolated from Dispholidus typus venom. Biochim. biophys. Acta 537, 160-168.

Hemker, H. C., Van Dam-Mieras, M. C. E. and Devilee, P. P. (1984) The action of Echis carinatus venom on the blood coagulation system. Demonstration of an activator of factor X. Thromb. Res. 35, 1-9.

HoFMANN, H. and BON, C. (1987a) Blood coagulation induced by the venom of Bothrops atrox. 1. Identification, purification and properties of a prothrombin activator. Biochemistry 26, 772-780.

HofmANn, H. and BoN, C. (1987b) Blood coagulation induced by the venom of Bothrops atrox. 2. Identification, purification and properties of two factor $X$ activators. Biochemistry 26, 780-787.

KISIEL, W. (1979) Molecular properties of the factor V-activating enzyme from Russell's viper venom. J. biol. Chem. 254, 12230-12234.

LAEMmLI, U. K. (1970) Cleavage of structural protein during the assembly of the head of bacteriophage T4. Nature 227, 680-685.

Lindhout, T., Govers-Riemslag, J. W. P., Van de WaArt, P., Hemker, H. C. and Rosing, J. (1982) Factor Xafactor $\mathrm{Va}$ interaction. The effect of phospholipid vesicles of varying composition. Biochemistry 21, 5494-5502.

Mertens, K. and Bertina, R. M. (1980) Pathways in the activation of human coagulation factor X. Biochem. J. 185, 647-658.

Nahas, L., Kamigutti, A. S. and Barros, M. A. R. (1979) Thrombin-like and factor X-activator components of Bothrops snake venoms. Thromb. Haemostas. 41, 314-328.

Pirkle, H. and Markland, Jr, F. S. (1988) Hemostasis and animal venoms. New York, Basel: Marcel Dekker, Inc.

Rosing, J. and TANS, G. (1988) Meizothrombin, a major product of factor Xa-catalyzed prothrombin activation. Thomb. Haemostas. 60, 355-360.

Rosing, J., Tans, G., Govers-Riemslag, J. W. P., Zwal, R. F. A. and Hemker, H. C. (1980) The role of phospholipids and factor $\mathrm{Va}$ in the prothrombinase complex. J. biol. Chem. 255, 274-283.

Rosing, J., ZWAaL, R. F. A. and TANS, G. (1986) Formation of meizothrombin as an intermediate in factor Xacatalyzed prothrombin activation. J. biol. Chem. 261, 4224-4228.

SChitCK, A., Kornalik, F. and HabermanN, E. (1972) The prothrombin activating principle from Echis carinatus venom. I. Preparation and biochemical properties. Naunyn-Schmiedeberg's Arch. Pharmacol. 272, $402-416$.

Schiffmann, S., Theodor, J. and RAPAPORT, S. J. (1969) Separation from Russell's viper venom of one fraction reacting with factor $X$ and another reacting with factor V. Biochemistry 8, 1397-1405.

SMTTH, R. L. (1973) Titration of activated bovine factor X. J. biol. Chem. 218, 2418-2423.

Speier, H., Govers-Riemslag, J. W. P., ZwaAl, R. F. A. and Rosing, J. (1986) Prothrombin activation by an activator from the venom of Oxyuranus scutellatus (Taipan snake). J. biol. Chem. 261, 13258-13267.

Stocker, K., Fischer, H. and Brogli, M. (1986) Determination of a factor X activator in the venom of the sawscaled viper (Echis carinatus). Toxicon 24, 313-315.

SuzUKI, K., DAHLbaCk, B. and Stenflo, J. (1982) Thrombin-catalyzed activation of human coagulation factor V. J. biol. Chem. 257, 6556-6564.

Tans, G., Govers-Riemslag, J. W. P., Van Run, J. L. M. L. and Rosing, J. (1985) Purification and properties of a prothrombin activator from the venom of Notechis scutatus scutatus. J. biol. Chem. 260, 9366-9372.

TANS, G., JANSSEN-Claessen, T. and Rosing, J. (1989) Amidolytic detection of prothrombin activation products after SDS-gel electrophoresis. Thromb. Haemostas. 61, 386-391.

TOWBIn, H., StaEhELIN, T. and GoRDON J. (1979) Electrophoretic transfer of protein from polyacrylamide gels to nitrocellulose sheets. Procedure and some applications. Proc. Nat. Acad. Sci. U.S.A. 76, 4350-4356. 